\title{
Abnormal stock performance of late filing firms: additional investigation
}

\author{
Mikhail Pevzner** \\ Assistant Professor \\ George Mason University \\ 4400 University Drive, MS 5F4 \\ Fairfax, VA 22030 \\ Phone: (703) 993-1755 \\ Email: mpevzner@gmu.edu
}

\begin{abstract}
:
This paper examines whether the previously observed future under-performance of the portfolio of the late 10-K filing firms exists in post-EDGAR period and any reasons for the observed under-performance. I find that there is some evidence of under-performance of the portfolio of the late filing firms. I further find that in post-EDGAR period, the late filing firms have higher de-listing probabilities and that the observed under-performance is driven by the future negative stock performance of the sample of the de-listed late filing firms. I conclude that, in post EDGAR period the market generally correctly values late filing firms.
\end{abstract}

**Corresponding Author

I thank Rich Frankel, Tzachi Zach and participants in Washington University's Weekly Accounting Research Reviews for their helpful comments and suggestions. 


\section{Introduction}

This paper investigates the underlying causes of future stock-market underperformance of firms that do not file their annual financial statements with SEC within prescribed statutory deadlines (hereafter "late filers"). This phenomenon has been documented in Alford et al. (1994), but the reasons for its existence are not well understood. I study whether the observed future stock market under-performance exists in period since the adoption of electronic filing of financial statement with SEC via Electronic Data Gathering, Analysis and Retrieval System (EDGAR) in 1994 (postEDGAR period), and whether this under-performance a manifestation of known accounting anomaly such as Post-Earnings Announcement Drift (PEAD), or is related to special properties of late filing firms such as higher levels of bankruptcy risk and higher probabilities of future restatements and de-listings. I find that the under-performance of late filers exists in post-EDGAR period, is driven by those late filers that notify the market of their intention to file late (notifiers), their higher propensity to de-list from national exchanges due to performance reasons and to restate their financial statements. This relationship is robust to controlling for late filers' bankruptcy risk at the time of the filing deadline and magnitude of earnings surprises in the four quarters preceding the late filing event. This finding suggests that under-performance of the late filing firms' phenomenon exists incremental to controlling for PEAD and bankruptcy risk. However, my further tests reveal that the under-performance is driven by the small sample of the extreme performers and that upon exclusion of these firms from the sample, there is no evidence of the wide-spread under-performance among late filing firms. 
Alford et al. 1994 study the special late filers' properties in 1977-1985 and find that the late filers represent a non-random sample of firms that experience negative accounting and stock performance in the period of the late filing, and negative stock performance in the following fiscal period. However, Alford et al. do not explain the causes underlying the observed late filers' future under-performance . I suggest three hypotheses that explain the causes of this market under-performance. Since Alford et al. study late filers in the pre-EDGAR period, my first hypothesis suggests that the observed under-performance is caused by lack of sufficiently timely and widely available 10-K filing data in the pre-EDGAR period, thus preventing timely and complete market reaction to the late filing news at the time of the filing deadline. Easton and Zmijewski(1993) show that in the pre-EDGAR period, when filing process was paperbased, investor access to $10-\mathrm{K}$ filing information was delayed by SEC processing. This also made it impossible for investors to promptly react to absence of the financial statements. However, instituting EDGAR made it essentially costless for investors to monitor compliance with filing deadlines. All an investor has to do since EDGAR was adopted is to $\log$ in to SEC website within 24 hours of the deadline, and she will be able to see whether the firm of interest has filed its financial statements (Griffin, 1998). Thus, if the future under-performance Alford et al. observed is related to investor's inability to timely penalize firms for the filing delay, I conjecture that with the advent of EDGAR, the market negatively reacts to late filing news in post-EDGAR period and that this reaction is more complete, resulting in no significant negative future stock market underperformance. This conjecture is consistent with the result in Feldman et al. (2005) who find that investors negatively react to late filing notifications in the three-day window 
surrounding late filing notification date. I also am motivated in this prediction by the results from prior research showing that market's reaction to the release of $10-\mathrm{K}$ filings in post-EDGAR period is stronger, especially among small investors and firms with weaker information environments (Griffin, 1998), and by increased investor access to and use of 10-K/Q filing information documented in the post-EDGAR period (Asthana and Balsam, 2005).

My second hypothesis is that the observed future negative performance is unrelated to the market reaction to the late filing event, but rather a manifestation of the PostEarnings Announcement Drift. Late filers tend to experience negative accounting performance, making it more likely that they experience strong negative earnings surprises in that period. PEAD literature provides robust evidence that market underreacts to both positive and negative earnings surprises, as demonstrated by the positive correlation between future abnormal returns and earnings surprises in the preceding periods. Thus, I study whether controlling for PEAD explains the observed future underperformance.

My third hypothesis is motivated by the listing rules both New York Stock Exchange (NYSE) and NASDAQ have on their books requiring their client firms to be in compliance with the filing deadlines imposed by SEC. Failure to comply with these rules will be a cause for delisting the stock from these exchanges. Delisting returns due to poor performance are likely to be negative (Shumway, 1998). Market may not be sufficiently aware of these regulatory provisions and thus fails to appropriately react to the news of the filing delay, explaining future stock under-performance. 
Finally, prior research documents that late filing is frequently associated with the ongoing accounting problems and turnover in accounting personnel. This makes it more likely that the late filing firm will restate its financial statements later in the future.

Restatements are accompanied by significant stock price declines both before and at the time of the restatement (Hribar et al. 2004). Thus, if the late filing event is a significant predictor of restatements, failure to impound this information at the time of the late filing event will result in the observed under-reaction to the late filing news.

I first test whether the future under-performance of the late filing firms exists in the post-EDGAR period. I find that the under-performance exists primarily among small notifiers. However, the under-performance does not exist among firms that do not notify SEC of their intention to file late and simply miss the deadline. I further find that late filing firms face higher probability of future delisting than timely filing firms, and that among late filing firms, notifiers are more likely to delist in the future. I also find that late filing firms face higher restatement probabilities than the timely filing firms; however, I am unable to find the statistically significant association between notification status and restatement probability. Finally, I show that the future returns of the delisting late filing firms are significantly more negative than those late filing firms that do not delist. I do not find a statistically significant relation between future returns and restatement status. This result is robust for controlling for Post-Earnings Announcement Drift. I thus conclude that the observed under-performance is driven by market's inability to fully anticipate late filing notifying firms' higher propensity to get de-listed. Non-parametric tests further suggest that the number of delisting firms that drive average negative future under-performance is small; however, they tend to experience extreme negative 
performance (extreme delisters). Thus, I conclude that even though late filing is strongly associated with future delistings and restatements, the future negative stock performance of the portfolio of the late filers is driven by a small number of these extreme delisters. Once these extreme delisters are removed from the sample, the remaining sample of the late filers does not appear to under-perform.

My research results are of interest to both regulators and academics in light of the concerns recently expressed both by SEC and financial press over the increased incidence and potential negative implications of the late filings. I suggest that the investors should monitor late filing events closely as they tend to be associated with future delistings. However, the good news is that such extreme events tend to be rare, indicating that the market on average correctly prices late filing firms.

This paper is organized as follows. Section 2 describes the institutional

background on 10-K filing deadlines, reviews prior literature, develops hypotheses and research design. Section 3 discusses sample and descriptive statistics. Section 4 discusses empirical analyses, and Section 5 concludes.

\section{Motivation and Hypothesis development}

I begin by describing the regulatory aspects of the late filings of financial statements with the SEC and national stock exchanges. I then proceed to review prior research and develop hypotheses.

\subsection{Over-view of the institutional features}

Rule 12b-25 of 1934 Securities and Exchange Act governs situations where the SEC registrants are unable to meet filing deadlines for forms 10-K, 10-KSB (small 
business version), 20-F (foreign registrants), 11-K, 10-Q and 10-QSB. Under this rule, the firm must file a late filing notification form (known also as Form 12b-25, or, alternatively as NT-10K and NT-10Q, for annual and quarterly filings, respectively, no later than one day after the due date of the related form. SEC will consider form 10-K and $10-\mathrm{Q}$ to be timely filed if 1) missing information could not be timely filed by the due date without unreasonable effort or expense, 2) late filing notification form is filed on time, and 3) missing information is filed with SEC within 15 days of the original deadline (Hertz et al., 1997). Form 12b-25 must specify the reasons "causing the inability to file timely" the financial statements (ibid). Figure 1 illustrates how the expected timeline of the late filing notification and shows how late filing notification relates to the other earnings announcements and actual filings that take place after the firm's fiscal year-end.

\section{Figure 1:}

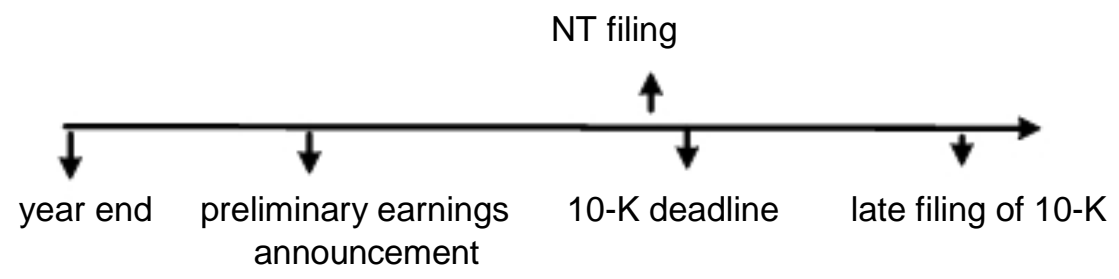

Recently, financial professionals and SEC regulators have voiced increasing concern over the late and delinquent 10-K and 10-Q SEC filings. In 2005 and 2006, SEC revoked registrations of a number of the SEC registrants that did not file their $10-\mathrm{Ks}$ for a number of years. Observers point out that these actions by SEC mark a significant change in SEC's attitude toward late filing of the financial statements, as in prior periods 
SEC rarely ever undertook such severe measures ${ }^{1}$. The concern over timely availability of the financial statements has become more recently pronounced among regulators partly as a result of the Sarbanes-Oxley Act regulatory changes. In response to the requirements of the Act, in 2002 SEC adopted new filing deadline rules for Accelerated filers, i.e. continuing U.S. SEC registrants with the public float (market value of equity owned by un-affiliated shareholders) over $\$ 75$ million. Effective December 15, 2002, these new rules shortened the Accelerated filers' filing 10-K deadlines from 90 to 75 days after the fiscal year end and 10-Q filing deadlines from 45 to 40 days after the fiscal quarter end. This deadline has been again shortened in late 2005 when SEC created another category of Large Accelerated filers, i.e. registrants with public float of over $\$ 700$ million. Large Accelerated filers have to file their 10-Ks/Qs within 60/40 days of the fiscal year end beginning December 15, 2006.

The basic motivation behind SEC's concern with the timely filings of the financial statements is emphasized in the following excerpt of the SEC release announcing shortening of the filing deadlines in 2003:

\begin{abstract}
The more extensive information in periodic reports is evaluated by investors and particularly analysts and institutional investors as a baseline for the incremental disclosures made by a company. These reports also contain more detailed information that is essential to conduct comparative analyses, as this information is often not contained in earnings releases or other incremental disclosures. Moreover, the information in Exchange Act reports, due to its required nature and the liability to which it is subject, provides a verification function against other statements made by the company in press releases and other public announcements. Investors and other users of the reports can judge previous informal statements by the company against the more extensive and mandated disclosure provided in the reports that have been reviewed by independent public accountants and other advisors...
\end{abstract}

(SEC Release 33-8128).

\footnotetext{
1

This is out of SEC's alleged belief that investors can themselves make appropriate conclusions about the firms whose financial statements are not available to the markets in the timely fashion (Sabatini 2004).
} 
The national exchanges are similarly concerned with timely filings of the financial statements. For example, on NASDAQ, failure to timely file financial statements will make the firm subject to delisting and will result in special modification of the firm ticker alerting investors of the lack of compliance with the exchange rules.

Just recently, NASDAQ notified four of its clients of initiating de-listing proceedings as a result of the failure to file the financial statements (Taub, 2005). NASDAQ lists noncompliant firms on its website ${ }^{2}$.

On NYSE, the ticker will be appropriately flagged within five business days after 15 days extension period allowed under Form 12b-25. NYSE also posts the names of the late filers on its website ${ }^{3}$. NYSE gives its firms 9 months to "cure" this violation of its listing rules, subject to additional 3 months extension, after which the firm will be delisted. However, these rules could be flexible. For example, in 2005, NYSE decided not to initiate the delisting proceedings against Fannie Mae which is yet to file its 2004 10-K. SEC gives NYSE a degree of discretion in enforcement of the stock listing rules, and thus NYSE could consider other factors, such as future and current firm performance in its decision whether to delist a stock if its financial statements have not been filed. (Taub, 2006).

\subsection{Review of the accounting literature}

Alford et al. (1994) study the late 10-K filings from1977 through 1985. They obtain $10-\mathrm{K}$ filing data from the special filing information data-base developed by Center for Research in Security Prices (CRSP). CRSP had to specifically request this data from

\footnotetext{
${ }^{2}$ See http://www.nasdaq.com/services/DelDefOpenReport.pdf

${ }^{3}$ For companies not in compliance with the NYSE filing requirements, see (http://www.nyse.com/Frameset.html?displayPage=/listed/1063018817872.html)
} 
the SEC, as no centralized filing data clearinghouse existed at the time, and EDGAR was to be fully instituted in 1994. Alford et al. focus on characteristics of the late filers and the stock market performance surrounding late filing of the financial statements. The paper finds that approximately $20 \%$ of all filers in their sample file their annual financial statements late, and that a total of about $2 \%$ of all filers are more than a month late in filing. Moreover, late filing firms tend to experience more negative average accounting and stock performance in the period of late filing than their timely filing peers. Not all firms that file their 10-Ks late end up filing late filing notification form NT-10K. Those firms that do file form NT-10K tend to have more negative performance than late filing firms that do not file form NT-10K. Alford et al. further analyze the reasons for late filings, provided in late filing notification forms, and find that a substantial percentage of firms filing financial statements late do so as a result of debt negotiations/restructurings and accounting problems/issues. Finally, the paper shows that late filing firms in their sample tend to have negative current abnormal returns both in the year and the quarter of delay, and also negative future abnormal returns implying market under-reaction to the late filing news. The negative future performance is more pronounced among notifying firms than among non-notifying firms. However, Alford et al. do not explain the reasons for this performance.

In a follow-up paper that uses a later sample incorporating EDGAR sample (see discussion below) and studies late filings of both 10-Ks and 10-Qs, Feldman et al. (2005) show that late filings notifications could be grouped into the following categories: auditor change and auditor-related delay, bankruptcy-related delay, delayed information, financial condition, management change and reorganization and restructuring. In the 
short-term return window analysis, Feldman et al. (2005) show that market generally reacts negatively to the news of the late filings, with most negative reaction being given to the firms experiencing bankruptcy-related delay and financial condition-related delay. This is consistent with Alford et al.'s finding of negative cumulative abnormal returns in the quarter of the late filings for the late filing firms in their sample. The significant difference between two studies is that Feldman et al. only analyze firms that notify SEC of their intentions to file form 10-K/Q late, while Alford et al. investigate all late filers of form 10-K, regardless of whether the late filing firms notify the SEC.

\subsection{Hypothesis development}

Alford et al. show that the late filings of $10-\mathrm{Ks}$ are associated with negative accounting and stock performance in the year of late filing (year $t$ ) and in the year following the late filing (year $t+1$ ). Moreover, the notifying firms have both more pronounced average negative accounting performance in year $t$ and in year $t+1$. Feldman et al. suggests also that market in the majority of cases reacts negatively to the late filing notifications. Taken together, the findings in these two papers suggest that market underreacts to the late filing notifications. Two reasons for under-reaction to the late filing news of the notifying firms are possible. First, notifying firms could have special features, such as weaker accounting systems, higher probability of fraud and restatements or future delistings that the market does not fully impound into prices at the time of the late filing. Alternatively, given observed reactions to the late filing notifications in Feldman et al., the market may react to late filing notification news more efficiently in the post-EDGAR period. Alford et al.'s study was conducted on the sample of late filing 
firms in 1979-1986, while Feldman et al. covers all late filing (both 10-K and 10-Q) firms in EDGAR database that started full operation in 1994. Easton and Zmijewski (1994) show that on average, in pre-EDGAR period, it could take up to five days between the SEC's receipt of the 10-K filing and its actual public release. However, in post-EDGAR period, investors are able to access electronically-submitted filings within 24 hours of submission via EDGAR website (Griffin, 1998). Thus, in post-EDGAR period investors should have stronger ability to monitor timely submissions of the 10-Ks or 10-Qs. Nothing is known about the efficiency of the market reactions to late filing notification in pre-EDGAR period. It is possible that in pre-EDGAR period, market simply did not have the means to notice the late filing event, unless it was notified of it. Alternatively it is possible that late filing events not accompanied by notifications did not warrant negative reactions. Asthana et al. (2004) show that with advent of EDGAR, small investors trade more actively trade on the late filing information. Griffin (1998) shows that market reacts stronger to $10-\mathrm{K}$ filings of firms with more poor information environment in postEDGAR period. Thus, these two papers suggest that EDGAR eased information access by investors, and thus also eased monitoring of the timely filing of the financial statements. Availability of EDGAR data thus allows us to answer whether the underperformance of the late filing firms is related to timely data availability, or to some other phenomenon associated with the late filers. Hence, I conjecture as follows:

Hypothesis 1: In the post-EDGAR period, market efficiently reacts to the late 10$\mathrm{K}$ filing news.

Since Alford et al. find that late filing firms, and especially notifiers, experience negative accounting performance in the period of the late filing, it is possible that the 
observed future negative abnormal returns are a manifestation of the market's underreaction to these firms negative earnings surprises (PEAD). This phenomenon has been widely analyzed in the accounting literature (see Bernard and Thomas, 1989, 1990, Ball and Bartov, 1996). Hence, we could observe negative future accounting performance among late filing firms independent of whether market monitors these firms' compliance with the filing deadlines. These two phenomena could co-exist, i.e. market could fail to appropriately penalize firms for their lateness and could at the same time fail to timely react to the prior four quarters' earnings surprises. As PEAD literature demonstrates, this results in a "drift" of the abnormal stock returns in the following accounting period. Empirically, PEAD manifests itself the same way as the under-reaction to the late filing bad news. Thus, it is an empirical question whether these two phenomena exist independently of each other. Hence, I conjecture:

Hypothesis 2: Future stock under-performance of the late filing firms is a manifestation of Post-Earnings Announcement Drift.

Financial press (Taub, 2004) has expressed concern that the increased incidence of the late filings could be related to the more extensive internal control problems preventing timely filings. Doyle et al. (2005) show that firms that report material internal control weaknesses have lower accrual quality. Accrual quality has been linked to increased probability of the future accounting restatements (Richardson et al. 2002). Prior literature also has linked more poor internal control structure to the higher incidence of restatements (Doyle et al. 2005). Restating firms tend to be high growth, high leverage firms that seek to obtain external financing at lower cost (Richardson et al. 2002). 
Additionally, restatements result in a substantially negative market reaction to the restatement announcement (Palmrose et al. 2004). Alford et al. document that late filing firms tend to be more highly leveraged, and that the debt renegotiations and internal accounting problems are the frequent causes of the late filings. Both higher dependence on the debt financing and stronger tendency to experience internal accounting problems make late filing firms be more susceptible to future earnings restatements. Additionally, Feldman et al. report that auditor changes and audit related-delays are among causes for impending late filings. Lazer et al. (2004) show that firms changing auditors tend to have higher restatement probabilities. All these factors suggest that late filing event should be associated with future restatements. Intuitively, late filing firms have strong interest to do all they can to avoid the restatement in part by delaying their filings with the SEC in light of known negative market reaction to restatement announcements (Palmrose et al. 2004 report it to be $-9 \%$ stock price decline, on average). Thus, I expect positive association between the late filings and future accounting restatements.

Hypothesis 3b: Late filings are positively associated with future restatements

Lawrence (1983) investigates the implications of reporting delays for the bankruptcy prediction models and shows that approximately $47 \%$ of the bankrupt firms in his sample experience filing delays. Both Alford et al. and Feldman et al. report that the debt renegotiation and bankruptcy proceedings are frequent reasons for the late filings. Financial distress is one reason for firms' future inability to meet national exchanges' listing requirements and subsequent future delistings (Dichev, 1998). Additionally, both 
NASDAQ and NYSE are concerned with the timely reporting of information and consider it a listing rules violation if a firm does not file financial statements to remain in compliance with the 1934 SEC Act (see above for the conditions of compliance). If the firm is not compliant, the delisting proceedings could be initiated against it. Based on my discussions with NYSE, this stock exchange will give up to additional nine months to the firm to cure the filing violation. NASDAQ does not have such a policy, and in the past has initiated delisting proceedings against some registrants within three days of the deadline $\mathrm{H}^{4}$ However, the scope and effectiveness of these delisting actions are un-known. National exchanges have to trade off the costs of the lack of available filing information

\footnotetext{
${ }^{4}$ Here is the example of the delisting due to late filing aaiPharma Announces Delay in 10-K Filing; Faces NASDAQ Delisting 03-17-2005
}

WILMINGTON -- aaiPharma Inc. (NASDAQ: AAII) has filed a Notification of Late Filing Report on Form 12b-25 with the Securities and Exchange Commission reporting that it will not file its 2004 Annual Report on Form 10-K today, the deadline for filing that report. aaiPharma Inc. is striving to file its 2004 Form 10-K as soon as possible. However, it did not represent in its Form 12b-25 filing that it would be able to file its 2004 Form 10-K by March 31, which is required by SEC rules to obtain a 15-day extension of the filing deadline, because aaiPharma Inc. believes it will not be able to file its 2004 Form 10-K by that date.

As a result of its failure to file the 2004 Form 10-K by March 16, 2005, aaiPharma Inc. is no longer in compliance with conditions for the continued listing of the Company's common stock on the Nasdaq Stock Market under Nasdaq Marketplace Rule 4310(c)(14) and under the terms of the June 2004 decision of a Nasdaq Listing Qualifications Panel that had permitted continued listing of the Company's common stock. aaiPharma Inc. has notified Nasdaq of its violation of these conditions and has requested that its common stock be permitted to continue to be listed on the Nasdaq Stock Market if it files its 2004 Form 10-K by April 30, 2005. April 30, 2005 is the extended deadline that would have been applicable to aaiPharma Inc.'s filing of management's assessment of internal control over financial reporting and the related attestation report of its independent registered public accountants under an SEC order issued in November 2004 and applicable to smaller issuers like aaiPharma Inc. if they were to have filed its 2004 Form 10-K by March 16, 2005. As indicated in aaiPharma Inc.'s Notification of Late Filing, delay in the completion of management's assessment of internal control is a critical reason preventing the Company from timely filing its 2004 Form 10-K. Notwithstanding the request to Nasdaq, Nasdaq may determine to immediately suspend trading and cease listing of aaiPharma Inc.'s common stock. 
to investors against the benefits of having firms list their stocks with the exchanges. Thus, it is an empirical question as to the extent of the application of the delisting rules.

To sum up, both document correlation of bankruptcy risk and late filing status and exchanges' policy to delist firms for failure to meet listing requirements increase the probability of late filing firms' future delistings. Thus, I conjecture as follows:

Hypothesis 4: Ceteris paribus, late filing firms have higher probability of delisting than timely filing firms.

Finally, I finalize my conjecture that the observed under-performance of the late filing firms is related to their higher propensity to delist and have restatements in the future:

Hypothesis 5: Negative future abnormal returns of late filing firms are driven by delisting and restating late filing firms.

\section{Research design}

To test Hypothesis 1, I collect 10-K filing data and test whether late filers underperform in the post-EDGAR period.

I test Hypothesis 2 in conjunction with Hypothesis 5. I describe the research design for hypothesis 5 further below.

To test hypothesis 3, I follow the model of prediction of future restatements described in Richardson et al. (2002) to control for other known restatement 
determinants. I collect data on all filing firms with sufficient data availability and include a dummy variable Late $=1$ if the firm files its $10-\mathrm{K}$ late. The prediction model is as follows:

$\operatorname{Prob}($ Fut_Restatement $=1)=\alpha_{0}++\alpha_{1} *$ Late $_{i t}+\alpha_{2} * M V E_{i t}+\alpha_{3} * M T B_{i t}+\alpha_{4} * L E V_{i t}+$ $\alpha_{5} * R O A_{i t}+\alpha_{6} * R O A_{i t-1}+\alpha_{7} * \Delta E P S_{i t}+\alpha_{8} * \Delta E P S_{i t-1}+\alpha_{7} *$ Accruals $_{i t}+\alpha_{7} *$ Positive String ${ }_{i t}$ $+\varepsilon_{i}$

My prediction is that $a_{l}<0$. The control variables proxy for determinants of restatements as follows: MTB-market to book ratio proxies for firms with high growth prospects, LEV - total liabilities to equity ratio proxies for firms with high leverage, ROA and lagged ROA-returns on assets proxy for levels of firm earnings growth in the current and past period, $\triangle E P S$ and lagged $\triangle E P S$ proxy for growth in earnings per share in the current and past periods, Accruals defined as difference between earnings before extraordinary items and cash flows from operations (Hribar and Collins, 2000) deflated by prior period assets control for any earnings management in accruals, and Positive String is a dummy variable $=1$ if the firm experiences positive random walk or forecast error surprises in the year of the late filings.

To test hypothesis 4, I conduct the following regression:

$\operatorname{Prob}($ Fut_Delisting $=1)=\alpha_{0}+\alpha_{1} *$ Late $_{i t}+\alpha_{2} * M V E_{i t}+\alpha_{3} * A g e_{i t}+\alpha_{4} * B H A R 12_{i t}+$ $\alpha_{5}$ Price $_{i t}+\alpha_{6} *$ Volume $_{i t}+\varepsilon_{i}$

The dependent variable is $=1$ if the firm delists within 365 days of the filing deadline. I do not differentiate between performance related delistings (CRSP codes 400-600) and non-performance related delistings (such as mergers and acquisitons, however, my 
untabulated results show that the majority of the delisting firms in my sample do so due to performance reasons. Those delistings are all exchange-initiated).

The primary variable of interest is the dummy variable Late $=1$ if the firm is late in its 10 $\mathrm{K}$ filing.

My prediction is that $\alpha_{1}<0$

The control variables are as follows:

$M V E$-market value of equity in the end of the fiscal year.

Age-Number of years of the firm coverage on Compustat

BHAR12-12 months of abnormal return starting 12 months before the filing deadline;

Price-stock price at the filing deadline

Volume-number of shares traded at the deadline.

These variables have been used in prior studies to construct delisting probability models (see, for example, Li et al. 2005).

To test hypothesis 5, I conduct the following regression for the firms in the late filing sample:

$$
\begin{aligned}
& \text { FBHARI2 }=\alpha_{0}+\alpha_{1} * \text { Late }_{i t}+\alpha_{2} * \text { BHARI2 } 2_{t}+\alpha_{3} * S U E_{t-1}+\alpha_{4} * S U E_{t-2}+\alpha_{5} * S U E_{t-3}+ \\
& \alpha_{6} * S U E_{t-4}+\alpha_{7} * \text { LATE }^{*} \text { Fut_Delist }+\alpha_{8} * \text { Restate }_{t}+\alpha_{9} * \text { Restate }^{*} \text { Late }_{t}+\varepsilon_{i}
\end{aligned}
$$

The dependent variable FBHAR12 is 12 month size-adjusted buy and hold abnormal return cumulated for 12 month beginning at the filing deadline.

If the under-reaction is robust to controlling for PEAD, then we should observe $\alpha_{1}<0$. 
SUEs are either random walk earnings surprises or analyst forecast errors earnings surprises of firms in the samples in quarters of 1-4 of the filing year.

Fut_Delist is a dummy variable=1 if the firm delists in the 12 month period following the deadline;

Restate is a dummy variable $=1$ if the firm restates in the 12 month period following the deadline.

If the returns are primarily driven by future restatements and delistingsI expect that $\alpha_{7}<0$ and $\alpha_{9}<0$.

\subsection{Data and descriptive statistics}

\subsection{Data and sample selection}

I collect $10-\mathrm{K}$ filing data using $10 \mathrm{KWizard}$ Database which in turnobtains the filing data live feed from EDGAR starting at 1994. My sample period ends in 2004. . Table 1, Panel A summarizes sample selection. I start with the sample of 71,599 10-K filings. The requirement of Compustat coverage reduces this sample to 44,675 filings. Additionally, I require that the filing firms have one year of monthly returns, ending at the filing deadline, (for the fiscal year of filing) available on CRSP. This reduces the sample of all available $10-\mathrm{Ks}$ to 37,319 observations. I then estimate the statutory deadlines for these filings on the basis of SEC rules effective at the end of each respective fiscal year. Table 1, Panel B summarizes the relative distribution of firms that file within the deadline (timely filers) and those that do not (late filers). Timely filers constitute 31,664 firm-years, or $85 \%$ of the original sample of all available filers, and late filers constitute 5,655 firm years, or $15 \%$ of the original sample. The proportion of the late 
filers in the sample of all filers is in line with the number of late filers reported in preEDGAR period by Alford et al who report that the late filers constitute $19 \%$ of all filers in their sample. Table 1, Panel C shows the composition of late filing firms by year as a percentage of the total filers covered by Compustat and available CRSP data. We can see that the percentage of the late filers usually fluctuates between 5 and $12 \%$, with only exception being the period between December 15, 2002 and December 31, 2002 when the number and percentage of the late filings surged to 1,863 or $57 \%$, respectively. On December 15, 2002, the new Accelerated Filing Deadline went into effect, and the firms with December 31, 2002 year end where the ones most negatively affected by it. Corresponding to the deadline change, we see the surge in the number of the late filers in that period. Bryant et al. (2005) show that when this deadline change went into effect, some firms had difficulty meeting it due to increased demands imposed by the regulators on these firms' accounting systems. Bryant et al. do not find any significant differences in subsequent accounting quality between their sample of timely and late filers affected by the deadline change, indicating that these firms lateness is driven primarily by the adjustment to new regulatory environment and not by special properties that contribute to the late filing identified both in Alford et al. and Feldman et al. Inability to meet the deadline due to regulatory change shock is not a part of my research question, and I therefore exclude all late filings firms (1,863 observations) with the year end between December 15, 2002 and December 31, 2002 from my analysis. The final sample consists of 3,750 observations.

Table 1, Panel D shows the distribution of observations in my sample by filing lag and NT status (NT=0 implies that the firm did not notify SEC of its intent to file late, and 
NT=1 implies that it did). The majority of the late filings $(3,081$ or $82 \%)$ are filed within 15 days of the filing deadline, and only $11 \%$ of the late filers take more than 20 days to file. This is generally consistent with the filing lag distribution documented in Alford et al. This distribution is consistent with the enforcement provisions employed by both SEC and National Exchanges, as past 20 days the Exchanges will be likely to notify investors of these firms' non-compliance with 1934 SEC Act. The un-tabulated results show that that the late filing firms are pre-dominantly NASDAQ firms (62\%), followed by NYSE $(15 \%)$ and $\operatorname{AMEX}(13 \%)^{5}$.

Additionally, $61 \%$ of all late filers notify the SEC of their intention to file late. Non-notifiers constitute $39 \%$ of the overall late filing sample. $90 \%$ of the non-notifiers $(\mathrm{NT}=0)$ are firms that fall into 15 day filing category, potentially indicating the nonnotifying firm believe that as long as they file within 15 days allowed if the firm notifies of the late filing, SEC will not penalize the non-notifying firms for the late filings. Conversely, when the delay is more pronounced, the late filing firms are much more likely to notify the SEC of the impending late filing in order to make sure timely disclosure under the Securities Laws.

\subsection{Descriptive Statistics}

Table 2, Panel A summarizes the descriptive statistics for the overall sample of the late filing firms. The mean (median) market value of equity of the firms in the sample is $\$ 649$ million (\$69 million), indicating that the majority of the late filing firms tend to be small. They also tend to have negative mean current and future ROA of $-0.14 /-0.02$, and experience slight increases in EPS in the year following the late filing. The mean (median) market-to-book ratio of 4.95 (1.57) shows that late filing firms tend to be

${ }_{5}$ CRSP history file did not provide information on the exchange status of about $10 \%$ of the firms in the sample. 
growth firms. The mean (median) debt-to-equity ratio of 4.43 (1.21) shows that they are more heavily leveraged. All of these indicators are consistent with findings in Alford et al. Hence, the nature and composition of the late filing firms before and after EDGAR adoption did not significantly change.

Additionally, I report the descriptive statistics for size-adjusted buy-and-hold abnormal returns (BHAR) for the year before, the year of, and the year after the late filing on both quarterly and annual level, cumulated starting at the fiscal year end date. For comparison, I also report 12 months BHAR, cumulated starting at the deadline.

The late filing firms in my sample experience abnormal negative performance in the year of late filing as shown by mean (median) negative annual BHAR of -0.15 (0.27). This negative performance appears to intensify in the third and fourth quarter of the late filing year when mean(median) BHARs are $-0.05(-0.07)$ and -0.06 (-0.09), respectively. Consistent with Alford et al, in the 12 month period following the end of the fiscal year of the late filing, I observe statistically significant negative mean (median) BHAR $-0.05(-0.18)$,. However, this is the an abnormal return cumulated at the end of the fiscal year, whereas the late filing event occurs either 90 or 75 days later. Significantly, in this sample, mean BHAR that is cumulated starting at the filing deadline, is not significant, indicating that on average trading strategy that would short all late filers beginning at the filing date would not be profitable.

The small median market value of equity of the firms in this sample suggests that it may be difficult to form a reliable trading strategy based on the future abnormal returns observed above. These returns, even though statistically significant, are economically very small. Additionally, very small firms are likely to have severe liquidity and shorting 
constraints making it impossible to implement the strategy. In the next step of my analysis, I therefore exclude any firms with the end-of-the-year market price less than $\$ 1$. I report the descriptive statistics for these firms in Table 2, Panel B. The results in this table are similar to those reported in Table 2, Panel A. Notably, however, the 12 months mean(median) abnormal return cumulated from the filing deadline is negative and significant $-0.04(-0.16)$, indicating that a potentially profitable strategy exists.

Table 3 presents the descriptive statistics of firms in my sample with stock price greater than $\$ 1$ broken down by size (less or greater than 200 million in market value of equity in the year of late filing) and NT status (NT=0 if the firm does not file form NT$10 \mathrm{~K}$ with the SEC and NT=1 if the firm files form NT-10K). I separate the firms in my sample in these four portfolios because the size of the firm is positively correlated with the firm information environment (such as analyst access, relative liquidity, etc.) and because Alford et al. have shown that notifying firms tend to experience distinctly worse performance in the year of the late filing than non-notifying firms, and in the year following the late filing. The results in Table 3 support Alford et al.'s findings. Across both size portfolios, notifying firms experience lower ROA and future ROA and stock performance in the following period. Also, consistent with prior research, both notifying and non-notifying firms experience negative abnormal stock performance and ROAs in the year of the late filing. ROAs remain reliably negative in the next year, without significant changes ${ }^{6}$. However, the abnormal returns in the year following the late filing year (cumulated beginning at the year end) are driven by notifying firms in both size categories. Non-notifying firms' abnormal returns in both the 12 months following the

6 Untabulated results suggest that late filing event does not have significant explanatory power with respect to future performance 
fiscal year end and 12 months following the deadline are not significant. For the small notifying firms (MVE<200 million), the mean(median) 12 month abnormal BHAR in the year $t+1$ starting at the deadline is-0.08(-0.28). For the large notifying firm (MVE $>=200)$ million, the corresponding mean return is not significant, while median return remains reliably negative -0.14 . Both small and large notifying firms have statistically significant negative abnormal returns in the 12 months following the end of the fiscal year suggesting that the market partially adjusts for the information contained in the late filing news in the period between the end of the fiscal year and the deadline. However, this only happens for large firms that have better monitoring. Small firms' information environment and analyst following tend to be smaller (Bhushan, 1989), and thus it follows from Table 3 that the market under-reacts to the information content of the late filings of the small firms. Also, a differential reaction to the late filing news of the notifying and non-notifying firms represents a significant difference between my findings and those of Alford et al. . In the un-tabulated results, I also find that if portfolio returns are calculated using daily abnormal returns starting one day after the deadline, notifying firms will have significant negative future size-adjusted returns in the period of 12 months following the deadline, than do non-notifying firms. Furthermore, these returns will be most pronounced among those notifiers that wait at least 12-13 days to file their 10-Ks, indicating that longer filing lag also communicates bad news.

Table 3, Panel B documents the differences in means between two matched samples of late filers and timely filers for a set of accounting and stock performance characteristics. . I match every late filing firm with the timely filing firm with closest market value of equity in the same two-digit SIC code, same year and same fiscal year 
end.. The test results show that the performance statistics of the non-notifying late firms (both large and small) are generally not statistically different than those of the matched timely firms, and in some cases non-notifying late filers even perform better than the timely filers. Also, subsequent period abnormal stock returns of the non-notifying late firms are generally not different than the abnormal stock returns of the matched timely firms. However, both current and future ROAs and current and future abnormal returns of the notifying late filers generally perform worse than the matched timely firms. Interestingly, the current and future ROA of notifying late filing firms are not significantly different. This indicates that the negative accounting performance of the late filing firms persists into the following period. The future ROA performance of the timely filing firms also gets worse on average, but the accounting performance of the late filing firms still remains significantly lower than accounting performance of the timely filing firms.

Consistent with Alford et al., late notifiers experience negative stock performance in the year of the late filing and in the following year. Late notifiers' stock performance is also reliably worse than that of the matched timely firms. However, I do not find significant differences in both current and following year stock performance of the late non-notifiers, a result different from that of Alford et al. who show weaker, yet statistically significant negative stock performance of non-notifying firms in both year $t$ and year $t+1$. I interpret this result to mean that notification decision is likely driven by either litigation risk or private information the management has about future performance. Late notifiers likely face significantly higher risk of shareholder litigation due to the observed poor accounting and stock performance. Failure to notify of the 
impending late filing accompanied by previous negative accounting and stock performance is likely to increase the probability of the shareholder lawsuits on the grounds of withholding information. Hence, given ex-post negative future accounting performance, management wants to avoid the allegations of withholding bad news from investors, and thus is more likely to notify the markets of the pending filing delay. Such behavior is consistent with firms' disclosing "bad news early" (Skinner 1994). In this case, "early bad news" is the late filing notification.

In the other hand, non-notifiers' performance is generally not significantly different from matched timely firms. Anecdotal evidence (Sabatini 2004) suggests that SEC rarely, if ever, sanctions late filers that file within reasonable time. Table 1, Panel D shows that 91\% of non-notifiers, file within 15 days of the deadline, making them, absent filing form NT10K, be in technical compliance with the 1934 SEC Act .Thus, it is possible that given low litigation risk involved, non-notifiers do not file form NT-10K because they know that they do not face shareholder and SEC actions on the grounds of sudden changes in future accounting or stock performance.

\section{Conclusion:}

The descriptive statistics analysis establishes that similarly to Alford et al.'s results, late filing notifying firms in post-EDGAR period under-perform in the 12 months following the filing deadline, suggesting that the under-performance phenomenon is unlikely to be driven by timely availability of the filing data on EDGAR. However, I find no evidence of under-performance of the non-notifying firms. Taken together, this evidence suggests that timely availability of the filing information is unlikely to play a serious role in the 
observed under-performance, as notification event should make it easier for investors to monitor late filing status.

\subsection{Regression analyses}

I begin by testing the relation between future restatements and late filing status. The restatement information is obtained from most recent available version of GAO Restatement Database. Only restatements made within one year of the filing deadline are considered. I estimate equation (1) using Logistic regression within the entire sample of filing firms (both timely and late) with available Compustat, CRSP and IBES data in Table 4. There are two versions of this model: the first one uses random walk quarterly earnings surprises to define dummy variable Positive String (Model 4A), and the second one uses analyst forecast errors to define that variable (Model 4B). The number of observations used to estimate Model 4B is significantly smaller (7,186 vs 23,246 in Model 4A) due to restrictions imposed by IBES analyst coverage. I truncate all continuous independent variables at $1 \%$ of each side of their respective distributions. In both versions of the model dummy variable Late is statistically significant, suggesting that late filing events are more likely to restate than the timely filing firms. Consistent with prior research, accruals and leverage are also significant predictors of restatements. My un-tabulated results, however, do not show significant association of the notification status of the late filing firms and probability of restatements of the late filing firms. I therefore conclude that notification of the late filing status plays a lesser role in the prediction of restatements than does the late filing event. 
I then proceed to investigate the relation between late filing status and future delistings. I obtain delisting data from CRSP Monthly History file. I estimate equation (2) in Table 5. Panel A of Table 5 investigates the relation between late filing status and future delisting status (Model 5A), and Panel B investigates the relation between notification status and delisting status for the late filing firms (Model 5B). In model 5A, late filing dummy variable is a significant predictor of future delisting. In this model, I included all delistings, whether company or exchange-initiated. Company initiated delistings often include mergers and acquisitions, voluntary "going private" transactions, etc. Exchange-initiated delistings are primarily driven by non-compliance with the exchange rules. In un-tabulated results, I only consider exchange-initiated delistings, and I find that the results are consistent with those in Table 5, Panel A., suggesting that the exchange-initiated delistings drive my results ${ }^{7}$. In Panel B of Table 5, I investigate the relation between filing notification status and probability of the delisting of the late filing firms. The variable NT=1 if the late filer notifies the SEC of the impending late filing. This variable is also significant, suggesting that the notifiers face much higher probability of delisting than non-notifiers ${ }^{8}$. Thus, the results in this Panel suggest that notifying firms experience face higher chances of delisting than non-notifying firms do.

In all, the results in Table 5 suggest that late filing firms in general, and late filing notifying firms in particular are strongly associated with higher future delisting prospects than their timely or non-notifying counterparts, respectively. Since delisting firms likely face highly negative performance preceding the delisting announcement, the results in

\footnotetext{
7 The result is also robust for controlling for the exchange status of the firm in the sample, suggesting that the exchange rules do not influence my result.

${ }^{8}$ The result is robust for controlling for the exchange status and considering only exchange initiated delistings (that estimation produces an even stronger result).
} 
Table 5 are consistent with Hypothesis 5 that delisting status plays a major role in the observed negative performance of the late filing firms.

I investigate this conjecture in Table 6. In Panel A, I estimate the regression of future abnormal returns of all filing firms in the sample on the late dummy, future restatement and delisting status, interactions of the late dummy and restatements/delisting dummies, and the set of variables controlling for any Post-Earnings Announcement Drift effects (to test Hypothesis 2). I run models in two different variations: the first one (Model 6A) incorporates random walk earnings surprise data to control for any PEAD under-reaction, and the second one (Model 6B) uses analyst forecast errors . The number of observations in Model 6B is considerably lower due to requirement of IBES coverage to estimate this model. I also control for any PEAD effects by incorporating 12 month buy-and-hold abnormal return from the year of the late filing as a control variable (BHAR12).

The estimation results are consistent with my expectations. The dummy variable late is significantly negative in both Model 6A and Model 6B, indicating, consistent with results in Table 3, that late filers perform worse in the following period than do timely filers. More interestingly, the interaction between delisting status and late filing status is even more negative (-0.46). This suggests that a delisting late filer earns negative future returns of $-0.5=-0.04-0.46$. The interaction of the late filing dummy with the future restatement dummy is not significant suggesting that restating late firms do not perform much worse than the restating timely firms. Additionally, surprise variables intended to control for separate PEAD effects are generally not significant, indicating either that PEAD effects are captured by significant BHAR12 variable, or that PEAD plays no 
significant role in under-performance of the late filing firms. However, these interaction results are not significant in Model 6B suggesting that their generalizability may be limited.

In all, Table 6, Panel A provides evidence that late filers that also delist experience strong future negative abnormal stock performance. The no-significance result in Model 6-B could be explained by the low power of that model induced IBES data availability requirements.

In order to assess the full impact of the future delistings on under-performance of the portfolio of the late filing firms, in Table 6, Panel B, I provide the break down of the future abnormal returns of various groupings of firms by size (MVE greater or less than 200 million), notification status and future delisting status. The results show that when delisting firms are removed from the sample, the future abnormal returns of the portfolio of the late filing firms are not significantly different from zero. As expected, the portfolios that entirely consist of the delisting firms experience very negative future returns. From this panel, it becomes clear why the portfolios of the notifying firms underperform. The delisting firms in the portfolio of notifying small firms (MVE200=0, $\mathrm{NT}=1$, DELIST $=1$ ) is -0.65 . This portfolio is only made up of 51 firms. Including these 51 observations in the sample is sufficient to produce a negative mean portfolio return of $8 \%$ we observed in Table 3.

One interesting observation that arises from this table is that the number of delisting firms in the portfolios is very small. This is because I require the that the delisting firms also have enough data to calculate the full 12 months of returns after the deadline, essentially restricting the analysis to delisting firms that delist in the end of this 
12 month period. However, in my analyses in Tables 4 and 5, I used every delisting observation within that 12 month period. Hence, as a sensitivity check I simulate 12 months of abnormal returns for those observations as well to evaluate the full extent at which delisting observations affect portfolio returns. I assign every delisting firm that is excluded from the analysis in Table 6, Panel B and that delists for performance reasons a delisting return of -1 and re-compute portfolio returns in the same way as I do in Panel B of Table 6. The results of this simulation are summarized in Panel C of Table 6. The results demonstrate that the abnormal returns again become very negative, particularly among small firms. However, due to the simulated nature of these results, they have to be interpreted with caution.

Thus, the empirical analyses in Tables 4-6 suggest that the late filing firms face higher probabilities of the future exchange initiated delisting and future restatements. Failure to fully impound this probability into the stock price at the time of the late filing will result in the inefficient valuation of the small notifying firms. This result is consistent with the weaker information environment that these firms likely have. My untabulated results show that small firms in the sample have an average analyst following of about 2 per firm, while large firms on average tend to have 6 analysts following them. This suggests that the under-reaction observed in that sample is driven by possible lack of investor attention to the late filing notification news.

Overall, no strong evidence that late filing firms severely under-perform in the future is found in this study. Thus, my results are at odds with those of Alford et al. My results potentially suggest that in post-EDGAR period investors' and analysts' ability to monitor the late filing events has improved. Alternatively, these results suggest that late 
filing event is not important to investors, since they are able to obtain value-relevant information from the other sources, such as preliminary earnings announcements. The latter conjecture is consistent with the results in Table 3 showing that 12 month abnormal returns of late filing firms cumulated from the end of the fiscal year are generally significantly negative, while only 12 month BHAR cumulated from the deadline for small notifiers is significant. This regularity suggests that markets obtain information about late filers during the period between the end of the fiscal year and the filing deadline. This is good news for regulators because it shows that the filing delay does not result in substantial disadvantage to investors, and thus despite the concerns over the late filings recently expressed in the financial press, late filings do not represent a serious problem from the valuation standpoint. .

\section{Conclusion}

I investigate whether late filing firms in post-EDGAR period continue to underperform following the late filing announcement. I find that a limited sub-sample of small late filing firms that notify the SEC continues to under-perform following the late filing announcement, and that this under-performance is driven by future delistings of these firms. I show that the late filing event has strong predictive power for future exchange initiated delistings and restatements, and that delistings are primary drivers of future under-performance among small late notifiers and that failure to account for increased probability of such delistings results in the observed under-reaction.

My research results are helpful to academics and regulators concerned with the increased incidence of the late filings in the U.S. I demonstrate that apart from the spike 
in the late filings that occurred as a result of the statutory deadline change in the end of 2002, late filing events are not more frequent in post-EDGAR period than in preEDGAR period, and that they generally do not result in mis-valuations of the late filing firms. Hence, my findings suggest that the markets are able to obtain information relevant to the valuations of those companies from sources other than $10-\mathrm{K}$, and lack of the verifiability associated with the late $10-\mathrm{K}$ generally does not disadvantage the investors. 


\section{References:}

Alford, A., J. Jones and M. Zmijewski (1994). Extensions and violations of the statutory SEC form 10-K filing requirements. Journal of Accounting and Economics, 17, 229-254

Asthana, S. and S. Balsam (2004). Differential Response of Small Versus Large Investors to 10-K Filings on EDGAR. The Accounting Review, July 2004

Ball, R. and E. Bartov (1996). How naïve is stock market's use of earnings information. Journal of Accounting and Economics 21(3)

Bernard, V. and J. Thomas (1990). Evidence that stock prices do not fully reflect the implications of current earnings for future earnings. Journal of Accounting and Economics, 13, 305-340

Bharath S., and T. Shumway (2004). Forecasting default with KMV-Merton Model. Working Paper. University of Michigan

Bhushan (1989). Firm characteristics and analyst following. Journal of Accounting and Economics, 11, 255-274

Bryant, L., E. Peng and K. Zvinakis (2005). Timeliness and quality of 10-K filings: the impact of the accelerated filing deadline. Working Paper, University of Oregon.

Doyle, J., Ge Weili, and S.McVay (2005). Accruals Quality and Internal Control over Financial Reporting. Working Paper, University of Utah, U of Michigan and NYU.

Easton, P. and M. Zmijewski (1993). SEC Form 10-K/10-Q reports and annual reports to shareholders: reporting lags and squared market model prediction errors. Journal of Accounting Research, 31(1), 113-129

Feldman, R., B. Rosenfeld, R. Lazar, J. Livnat, B. Segal (2005). Computerized retrieval and classification: an application to reasons for late filings with Securities and Exchange Commission. Intelligent Data Analysis, An International Journal, forthcoming.

Griffin, P. (2003). Got information? Investor Response to Form 10-K and Form 10-Q EDGAR filings. Review of Accounting Studies, 8, 433-460.

Hertz, R., N. Dittmar, S. Lis, W. Decker, R. Murray (1997). The Cooper's and Lybrand SEC Manual. Whiley

Hribar, P. and D. Collins (2002). Errors in estimating accruals: implications for empirical research. Journal of Accounting Research, 40(1), 101-134 
Lawrence E. (1983). Reporting delays for late filing firms. Journal of Accounting Research, 21(2), 606-610

Lazer, R., J. Livnat, C. Tan (2004). Restatements and accruals after auditor changes. Working Paper. NYU.

Li J., Zhang, L., and J. Zhou (2005). Earnings management and delisting risk: the case of IPO firms. Working Paper. University of Rochester.

Palmrose, Z., V. Richardson, and S. Scholz (2004).Determinants of market reactions to restatement announcements. Journal of Accounting and Economics, 37(1), 59-89.

Richardson, S., I. Tuna, and M. Wu (2002). Predicting earnings management: the case of earnings restatements. Working Paper. University of Pennsylvania and HKUST.

Securities and Exchange Commission Release No. 33-8128. Acceleration or Periodic Report Filing Dates and Disclosure Concerning Website Access to Reports. Available at http://www.sec.gov/rules/final/33-8128.htm

Sabatini, J. (2004). SEC Crackdown Not Relevant To Most Functioning Cos. Compliance Week, December 14, 2004

Skinner, D. (1994). Why firms voluntarily disclose bad news? Journal of Accounting Research, 32(1)

Taub, Stephen (2004). Firm Sees Filing Delays As Sign Of Control Weaknesses. Compliance Week, November 30, 2004.

Taub, Stephen and Dave Cook (2005). Late filers face delisting. Available at www.cfo.com, April 6, 2005.

Taub, Stephen (2006). The tale of two delinquent filers. Available at www.cfo.com. February 2, 2006.

Vassalou, M. and Y. Xing (2004). Default Risk in Equity Returns. Journal of Finance, LIX, 831-868 


\section{Table 1:}

\section{Panel A:}

\begin{tabular}{|l|r|}
\hline Total 10-K filings at the time of sample collection & 71,599 \\
\hline Data loss due to lack of Compustat coverage & $(26,605)$ \\
\hline Exclude any 2005 firms & $(319)$ \\
\hline & 44,675 \\
\hline & $(7,356)$ \\
\hline $\begin{array}{l}\text { Data loss due to lack of 12 months of contemporaneous } \\
\text { returns on CRSP }\end{array}$ & $\mathbf{3 7 , 3 1 9}$ \\
\hline $\begin{array}{l}\text { Total 10-K filings for which 12 months of returns before } \\
\text { the deadline is available }\end{array}$ & $(31,664)$ \\
\hline & $(33)$ \\
\hline \begin{tabular}{l} 
Exclude timely filing firms \\
\hline $\begin{array}{l}\text { Exclude late filing firms that delist before the filing } \\
\text { deadline }\end{array}$
\end{tabular} \\
\hline Loss due to availability of prior year assets & $(9)$ \\
\hline Late filing firms 1994-2003 & $(1,863)$ \\
\hline $\begin{array}{l}\text { Late filing firms subject to the deadline change as of } \\
\text { December 15, 2003 }\end{array}$ & 3,750 \\
\hline Late filings included in the final sample \\
\hline
\end{tabular}

\section{Table 1:}

Panel B: Relative distribution of timely and late filing firms

\begin{tabular}{|cccc|}
\hline All 10-K filings available in CRSP & $\#$ & $\begin{array}{c}\text { As \% of total } \\
\text { filings } \\
\text { available }\end{array}$ & $\begin{array}{c}\text { As \% of } \\
\text { all 10-K } \\
\text { filings in } \\
\text { EDGAR }\end{array}$ \\
\hline Timely filings & & & $85 \%$ \\
Late filings & 31,664 & $44 \%$ \\
& 5,655 & $15 \%$ & $8 \%$ \\
\cline { 2 - 4 } & 37,319 & $100 \%$ & $52 \%$ \\
\hline
\end{tabular}


Table 1:

Panel C: Relative distribution of timely and late filing firms by year of filing

\begin{tabular}{|c|c|c|c|}
\hline & $\begin{array}{l}\text { Late } \\
\text { filings }\end{array}$ & $\begin{array}{l}\text { All Filings } \\
\text { with } \\
\text { Available } \\
\text { Compusta } \\
\text { t and } \\
\text { CRSP } \\
\text { Data }\end{array}$ & $\begin{array}{l}\frac{\text { Late as }}{\text { a \% of }} \\
\frac{\text { Total }}{\text { Tota }}\end{array}$ \\
\hline 1993 & 27 & 854 & $3 \%$ \\
\hline 1994 & 58 & 1,220 & $5 \%$ \\
\hline 1995 & 166 & 1,994 & $8 \%$ \\
\hline 1996 & 289 & 3,368 & $9 \%$ \\
\hline 1997 & 307 & 3,579 & $9 \%$ \\
\hline 1998 & 446 & 3,572 & $12 \%$ \\
\hline 1999 & 382 & 3,377 & $11 \%$ \\
\hline 2000 & 283 & 3,401 & $8 \%$ \\
\hline 2001 & 276 & 3,250 & $8 \%$ \\
\hline 2002-before deadline change & 112 & 1,267 & $9 \%$ \\
\hline & 2,346 & 25,882 & \\
\hline 2002-after deadline change & 1,863 & 3,247 & $57 \%$ \\
\hline 2003 & 838 & 4,220 & $20 \%$ \\
\hline 2004 & 566 & 3,970 & $14 \%$ \\
\hline & 3,267 & 11,437 & \\
\hline Total late filings $1993-2004$ & 5,613 & 37,319 & $15 \%$ \\
\hline & & & \\
\hline
\end{tabular}


Table 1:

Panel D: Distribution of the late filing firms by filing lag (number of days late) and NT-status

\begin{tabular}{|c|c|c|c|c|c|c|c|}
\hline & NT Status & $\begin{array}{l}\text { Between } 0 \\
\text { A } \\
\text { and } 15 \\
\text { days late }\end{array}$ & $\begin{array}{l}\text { Between } \\
15 \text { and } 20 \\
\text { lat } \\
\text { days late } \\
\text { th }\end{array}$ & $\begin{array}{l}\text { Between } \\
20 \text { and } \\
60 \text { days }\end{array}$ & $\begin{array}{l}\text { Between } \\
60 \text { and } \\
100 \text { days }\end{array}$ & $\begin{array}{c}\text { More } \\
\text { than } \\
100 \\
\text { days }\end{array}$ & Total \\
\hline & No & 1,323 & 46 & 45 & 20 & 24 & 1,458 \\
\hline & Yes & 1,758 & 233 & 200 & 52 & 49 & 2,292 \\
\hline & Total & 3,081 & 279 & 245 & 72 & 73 & 3,750 \\
\hline As $\%$ of all & late firms in the sample & $82 \%$ & $7 \%$ & $7 \%$ & $2 \%$ & $2 \%$ & $100 \%$ \\
\hline
\end{tabular}


Table 2:

\section{Panel A: Descriptive Statistics for the overall sample}

\begin{tabular}{|c|c|c|c|c|c|c|c|}
\hline Variable & $\mathbf{N}$ & Mean & & Std Dev & $\begin{array}{l}\text { Lower } \\
\text { Quartile }\end{array}$ & Median & $\begin{array}{c}\text { Upper } \\
\text { Quartile }\end{array}$ \\
\hline mve & 3,750 & 649.13 & & $4,438.38$ & 19.80 & 68.61 & 223.16 \\
\hline roa & 3,727 & -0.14 & & 0.45 & -0.17 & -0.02 & 0.03 \\
\hline fut_roa & 2,798 & -0.14 & & 0.69 & -0.17 & -0.01 & 0.04 \\
\hline fut_earn_change & 2,797 & 0.05 & & 0.61 & -0.04 & 0.01 & 0.08 \\
\hline $\mathrm{mtb}$ & 3,737 & 4.95 & & 97.87 & 0.83 & 1.57 & 2.97 \\
\hline dte & 3,728 & 4.43 & & 88.96 & 0.41 & 1.21 & 3.15 \\
\hline bhar_pq1 & 3,440 & 0.01 & ** & 0.35 & -0.18 & -0.03 & 0.13 \\
\hline bhar_pq2 & 3,460 & 0.01 & * & 0.36 & -0.19 & -0.04 & 0.13 \\
\hline bhar_pq3 & 3,504 & -0.01 & & 0.41 & -0.20 & -0.05 & 0.11 \\
\hline bhar_pq4 & 3,531 & -0.02 & ** & 0.48 & -0.22 & -0.06 & 0.11 \\
\hline bhar_pyl & 3,437 & 0.00 & & 0.85 & -0.45 & -0.16 & 0.18 \\
\hline bhar_q1 & 3,734 & -0.03 & & 0.36 & -0.22 & -0.06 & 0.10 \\
\hline bhar_q2 & 3,750 & -0.03 & & 0.37 & -0.22 & -0.07 & 0.09 \\
\hline bhar_q3 & 3,750 & -0.05 & & 0.39 & -0.24 & -0.07 & 0.08 \\
\hline bhar_q4 & 3,750 & -0.06 & & 0.41 & -0.26 & -0.09 & 0.07 \\
\hline bhar_yl & 3,734 & -0.15 & & 0.76 & -0.54 & -0.27 & 0.05 \\
\hline bhar_fq1 & 3,258 & -0.02 & $* *$ & 0.38 & -0.21 & -0.05 & 0.10 \\
\hline bhar_fq2 & 3,246 & -0.02 & & 0.36 & -0.20 & -0.04 & 0.11 \\
\hline bhar_fq3 & 3,237 & -0.01 & & 0.45 & -0.21 & -0.05 & 0.10 \\
\hline bhar_fq4 & 3,233 & -0.02 & & 0.52 & -0.23 & -0.06 & 0.10 \\
\hline bhar_fyl & 3,232 & -0.05 & & 1.04 & -0.49 & -0.18 & 0.13 \\
\hline fbhar12 & 2,680 & -0.02 & & 1.10 & -0.49 & -0.17 & 0.17 \\
\hline
\end{tabular}

Variable definitions:

MVE-market value of equity in the end of the fiscal year;

ROA and FUT_ROA-Return on Assets defined as Earnings before Extra-ordinary items (data18) deflated by prior year total assets (data6)

FUT_EARN_CHANGE-Change in next year basic earnings per share (data58)

MTB-market to book ratio defined as MVE deflated by book value (data60)

DTE-Debt to equity ratio defined as total liabilities (data181) deflated by book value (data60)

BHAR_pq1-BHAR-pq4-quarterly buy-and-hold size-adjusted abnormal returns in the fiscal year prior to the late filing year

BHAR-q1-BHAR-q4-quarterly buy-and-hold size-adjusted abnormal returns in the fiscal year of late filing BHAR_fq1-BHAR_fq4-quarterly buy-and-hold size-adjusted abnormal returns in the fiscal year following the late filing

BHAR_fyl-12 month buy-and-hold size-adjusted abnormal return in the fiscal year following the late filing FBHAR12-12 month buy-and-hold size-adjusted abnormal return in the year following the filing deadline 


\section{Panel B: Descriptive Statistics of the late filing firms with end of the year stock}

\section{price $>\$ 1$}

\begin{tabular}{|c|c|c|c|c|c|c|c|}
\hline Variable & $\mathbf{N}$ & Mean & & Std Dev & $\begin{array}{c}\text { Lower } \\
\text { Quartile } \\
\end{array}$ & Median & $\begin{array}{c}\text { Upper } \\
\text { Quartile } \\
\end{array}$ \\
\hline mve & 3,309 & 733.13 & & $4,718.61$ & 30.28 & 86.87 & 270.20 \\
\hline roa & 3,286 & -0.10 & & 0.40 & -0.13 & 0.00 & 0.04 \\
\hline fut_roa & 2,471 & -0.12 & & 0.69 & -0.13 & 0.00 & 0.04 \\
\hline earn_chan & 2,470 & 0.02 & * & 0.44 & -0.04 & 0.01 & 0.06 \\
\hline mtb & 3,296 & 5.41 & & 104.02 & 0.98 & 1.65 & 3.04 \\
\hline dte & 3,287 & 4.44 & & 91.04 & 0.45 & 1.23 & 3.16 \\
\hline bhar_pq1 & 3,039 & 0.02 & & 0.34 & -0.16 & -0.03 & 0.13 \\
\hline bhar_pq2 & 3,056 & 0.02 & & 0.35 & -0.18 & -0.02 & 0.14 \\
\hline bhar_pq3 & 3,090 & 0.01 & & 0.41 & -0.18 & -0.04 & 0.12 \\
\hline bhar_pq4 & 3,114 & 0.00 & & 0.48 & -0.20 & -0.05 & 0.11 \\
\hline bhar_pyl & 3,036 & 0.04 & ** & 0.87 & -0.41 & -0.13 & 0.21 \\
\hline bhar_q1 & 3,294 & -0.02 & & 0.33 & -0.20 & -0.05 & 0.11 \\
\hline bhar_q2 & 3,309 & -0.02 & & 0.36 & -0.20 & -0.05 & 0.10 \\
\hline bhar_q3 & 3,309 & -0.03 & & 0.39 & -0.21 & -0.06 & 0.09 \\
\hline bhar_q4 & 3,309 & -0.03 & & 0.40 & -0.22 & -0.07 & 0.09 \\
\hline bhar_yl & 3,294 & -0.09 & & 0.78 & -0.48 & -0.21 & 0.09 \\
\hline bhar_fq1 & 2,990 & -0.03 & & 0.32 & -0.21 & -0.05 & 0.10 \\
\hline bhar_fq2 & 2,983 & -0.03 & & 0.33 & -0.19 & -0.04 & 0.10 \\
\hline bhar_fq3 & 2,977 & -0.02 & & 0.36 & -0.20 & -0.04 & 0.10 \\
\hline bhar_fq4 & 2,974 & -0.03 & & 0.42 & -0.22 & -0.06 & 0.10 \\
\hline bhar_fyl & 2,973 & -0.08 & & 0.81 & -0.48 & -0.18 & 0.13 \\
\hline fbhar12 & 2,465 & -0.04 & & 0.84 & -0.47 & -0.16 & 0.15 \\
\hline
\end{tabular}

Variable definitions:

MVE-market value of equity in the end of the fiscal year;

ROA and FUT_ROA-Return on Assets defined as Earnings before Extra-ordinary items (data18) deflated by prior year total assets (data6)

FUT_EARN_CHANGE-Change in next year basic earnings per share (data58)

MTB-market to book ratio defined as MVE deflated by book value (data60)

DTE-Debt to equity ratio defined as total liabilities (data181) deflated by book value (data60)

BHAR_pq1-BHAR-pq4-quarterly buy-and-hold size-adjusted abnormal returns in the fiscal year prior to the late filing year

BHAR-q1-BHAR-q4-quarterly buy-and-hold size-adjusted abnormal returns in the fiscal year of late filing BHAR_fq1-BHAR_fq4-quarterly buy-and-hold size-adjusted abnormal returns in the fiscal year following the late filing

BHAR_fyl-12 month buy-and-hold size-adjusted abnormal return in the fiscal year following the late filing FBHAR12-12 month buy-and-hold size-adjusted abnormal return in the year following the filing deadline 
Table 3:

Panel A:

Descriptive statistics of the late filing firms with stock price $>\$ 1$ broken down by size and NT status

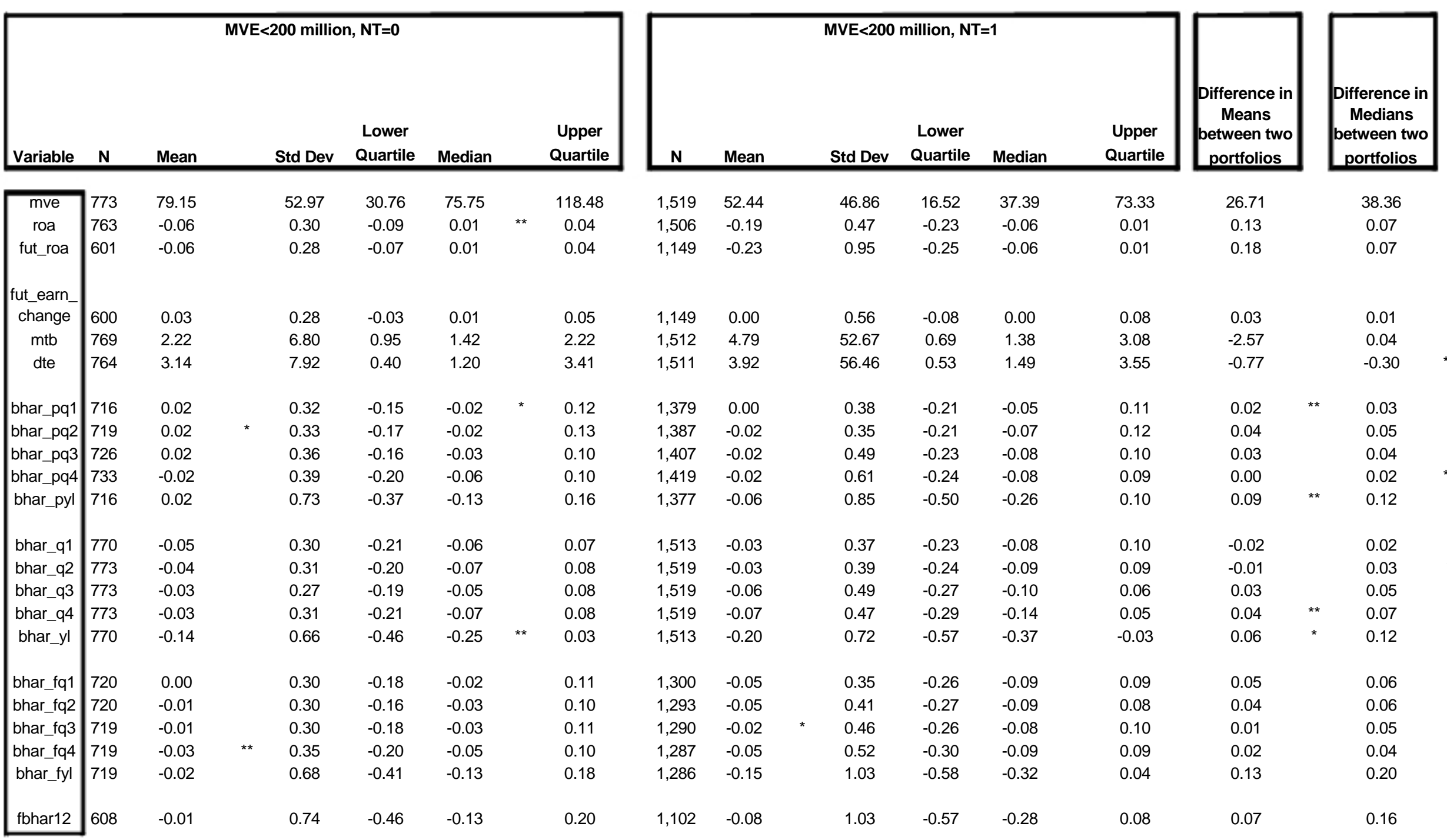


Table 3 Panel A (continued)

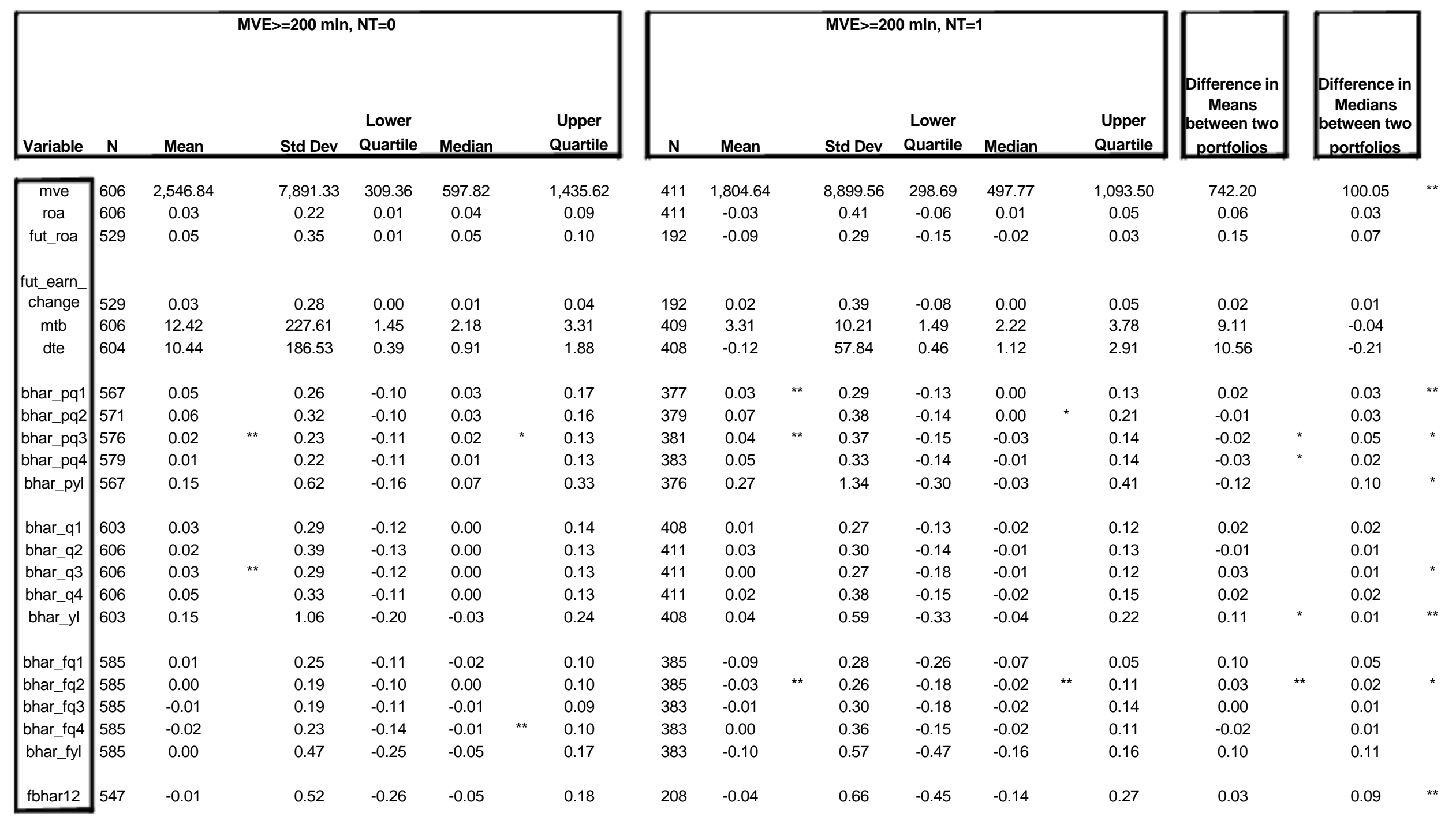


Variable definitions:

MVE-market value of equity in the end of the fiscal year;

ROA and FUT_ROA-Return on Assets defined as Earnings before Extra-ordinary items (data18) deflated by prior year total assets (data6)

FUT_EARN_CHANGE-Change in next year basic earnings per share (data58)

MTB-market to book ratio defined as MVE deflated by book value (data60)

DTE-Debt to equity ratio defined as total liabilities (data181) deflated by book value (data60)

BHAR_pq1-BHAR-pq4-quarterly buy-and-hold size-adjusted abnormal returns in the fiscal year prior to the late filing year

BHAR-q1-BHAR-q4-quarterly buy-and-hold size-adjusted abnormal returns in the fiscal year of late filing

BHAR_fq1-BHAR_fq4-quarterly buy-and-hold size-adjusted abnormal returns in the fiscal year following the late filing

BHAR_fyl-12 month buy-and-hold size-adjusted abnormal return in the fiscal year following the late filing

FBHAR12-12 month buy-and-hold size-adjusted abnormal return in the year following the filing deadline 
bhar12

bhar_fyl

bhar_fq1

bhar_fq2

bhar_fq3

bhar_fq4
615

550

553

551

550

550
$-0.033$

0.023

0.0036

0.0322

0.0088

$-0.027$

MVE $>=200$ million, NT=0;

\section{7}

398

fut_roa

fut_eps_change

bhar12

bhar_fyl

bhar_fa1

bhar_fq2

bhar_fq3

bhar_fq4
$-0.029$

$-0.039$

0.0071

0.2227

0.0607

0.0356

$-0.032$

$-0.004$

0.0606

MVE<200 million, NT=1;

$\begin{array}{cc}\text { roa } & 1,515 \\ \text { fut_roa } & 1,518 \\ \text { fut_eps_change } & 1,376 \\ \text { bhar12 } & 1,521 \\ \text { bhar_fyl } & 1,387 \\ \text { bhar_f1 } & 1,392 \\ \text { bhar_fq2 } & 1,392 \\ \text { bhar_f3 } & 1,391 \\ \text { bhar_fq4 } & 1,387\end{array}$

$-0.069$

$-0.131$

0.0774

$-0.086$

0.0859

0.0623

0.0232

$-0.007$

$-0.014$
$-0.11$

0.0201

0.0312

0.0094

$-0.011$

$-0.041$

0.0187

0.0486

0.0189

0.1101

$-0.004$

0.0127

0.0087

$-0.014$

$-0.029$

MVE >=200 million, NT=1;

roa
fut_roa
fut_eps_change
bhar12
bhar_fyl
bhar_fq1
bhar_fq2
bhar_fq3
bhar_fq4

\section{2}

212

0.0018

$-0.011$

0.0264

0.1257

$-0.049$

0.0339

$-0.026$

$-0.019$

$-0.038$

$\begin{array}{cc}-0.102 & 0.1038 \\ -0.107 & 0.096 \\ 0.0943 & -0.0679 \\ -0.077 & 0.2027 \\ -0.193 & 0.144 \\ -0.135 & 0.1689 \\ -0.037 & 0.011 \\ -0.056 & 0.037 \\ -0.013 & -0.025\end{array}$

0.185

0.132

0.3334

0.228

0.1559

0.0783

0.0612

0.013

0.005 
MTB-market to book ratio defined as MVE deflated by book value (data60)

DTE-Debt to equity ratio defined as total liabilities (data181) deflated by book value (data60)

BHAR_pq1-BHAR-pq4-quarterly buy-and-hold size-adjusted abnormal returns in the fiscal year prior to the late filing

\section{year}

BHAR-q1-BHAR-q4-quarterly buy-and-hold size-adjusted abnormal returns in the fiscal year of late filing

BHAR_fq1-BHAR_fq4-quarterly buy-and-hold size-adjusted abnormal returns in the fiscal year following the late filing

BHAR_fyl-12 month buy-and-hold size-adjusted abnormal return in the fiscal year following the late filing

FBHAR12-12 month buy-and-hold size-adjusted abnormal return in the year following the filing deadline 


\begin{tabular}{|c|c|c|c|c|c|c|c|}
\hline \multirow[b]{2}{*}{ Variable } & \multirow[b]{2}{*}{$\begin{array}{c}\text { Expected } \\
\text { Sign }\end{array}$} & \multicolumn{3}{|c|}{ Model 4A } & \multicolumn{3}{|c|}{ Mode4B } \\
\hline & & $\begin{array}{c}\text { Coefficient } \\
\text { estimate }\end{array}$ & -value & \begin{tabular}{|c|}
$\begin{array}{c}\text { Odds- } \\
\text { Ratio } \\
\text { (point } \\
\text { estimate) }\end{array}$ \\
\end{tabular} & $\begin{array}{l}\text { Coefficient } \\
\text { estimate }\end{array}$ & p-value & $\begin{array}{c}\text { Odds- } \\
\text { Ratio } \\
\text { (point } \\
\text { estimate) }\end{array}$ \\
\hline $\begin{array}{l}\text { INTERCEPT } \\
\text { Test variables }\end{array}$ & $?$ & -4.37 & $<0.0001$ & & -4.39 & $<0.0001$ & \\
\hline $\begin{array}{l}\text { Late } \\
\text { Control variables } \\
\end{array}$ & + & 0.73 & $<0.0001$ & 2.08 & 0.72 & 0.05 & 1.85 \\
\hline MVE & + & 0.00 & 0.13 & 1 & 0.00 & 0.56 & 1 \\
\hline МТB & + & -0.00 & 0.45 & 1 & -0.01 & 0.03 & 0.99 \\
\hline Lev & + & 0.01 & 0.09 & 1.01 & 0.06 & 0.01 & 1.06 \\
\hline ROA & $?$ & -1.55 & 0.02 & 0.21 & -0.07 & 0.96 & 0.93 \\
\hline Prior year ROA & + & 0.7 & 0.27 & 2.02 & -0.77 & 0.25 & 0.46 \\
\hline$\Delta \mathrm{EPS}$ & + & -0.01 & 0.90 & 0.98 & -0.91 & 0.28 & 0.40 \\
\hline Prior year $\triangle \mathrm{EPS}$ & + & -0.04 & 0.67 & 0.94 & -1.78 & 0.10 & 0.16 \\
\hline $\begin{array}{l}\text { Accruals } \\
\text { Estimated default }\end{array}$ & + & 1.78 & 0.01 & 5.92 & 2.69 & 0.07 & 14.74 \\
\hline $\begin{array}{l}\text { frequency } \\
\text { Positive-String } \\
\text { (random walk) }\end{array}$ & + & $\begin{array}{l}0.52 \\
-0.09\end{array}$ & $\begin{array}{l}0.12 \\
0.62\end{array}$ & $\begin{array}{l}1.69 \\
0.91\end{array}$ & 0.99 & 0.11 & 2.7 \\
\hline $\begin{array}{l}\text { Positive-String } \\
\text { (forecast errors) }\end{array}$ & & & & & 0.13 & 0.68 & 1.14 \\
\hline Pseudo-R2 & & & & & 0.002 & & \\
\hline
\end{tabular}

All explanatory variables have been truncated at $1 \%$ level.

\section{Variables Definitions:}

LATE-a dummy variable coded 1 for all late filing firms and 0 otherwise;

MVE-market value of equity in the end of the fiscal year;

MTB-market to book ratio

LEV-leverage (total liabilities deflated by equity)

ROA-return on assets

$\triangle$ EPS-change in basic EPS in the year of late filing

Accruals-Earnings before extraordinary items minus cash flows from operations, deflated by total assets in prior period (data18-data308)/data6 ${ }_{t-1}$

Estimated default frequency-measure of bankruptcy risk in KMV-Merton model

Positive String=1 if all random walk (forecast errors) earnings surprises in the vear of late filing are positive 


\begin{tabular}{|c|c|c|c|c|}
\hline \multirow[b]{2}{*}{ Variable } & \multirow[b]{2}{*}{ Expected Sign } & \multicolumn{3}{|c|}{ Model 5A } \\
\hline & & Coefficient estimate & -value & 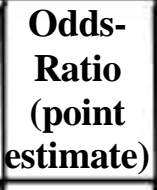 \\
\hline $\begin{array}{l}\text { INTERCEPT } \\
\text { Test variables }\end{array}$ & $?$ & -2.01 & $<0.001$ & \\
\hline $\begin{array}{l}\text { Late } \\
\text { Control variables } \\
\end{array}$ & + & 0.42 & $<0.001$ & 1.51 \\
\hline MVE & - & 0.00 & 0.22 & 1 \\
\hline Age & $?$ & -0.01 & $<0.001$ & 0.99 \\
\hline BHAR12 & - & -0.12 & 0.07 & 1 \\
\hline Stock Price & - & -0.009 & 0.01 & 0.99 \\
\hline Volume & - & 0.00 & 0.06 & 1 \\
\hline $\begin{array}{l}\text { Shares outstanding } \\
\text { Estimated default } \\
\text { frequency } \\
\text { Pseudo-R2 }\end{array}$ & + & $\begin{array}{l}-0.00 \\
1.57\end{array}$ & $\begin{array}{l}<0.001 \\
<0.0001\end{array}$ & $\begin{array}{c}1 \\
6.14\end{array}$ \\
\hline
\end{tabular}

All explanatory variables have been truncated at $1 \%$ level.

\section{Variables Definitions:}

LATE-a dummy variable coded 1 for all late filing firms and 0 otherwise;

MVE-market value of equity in the end of the fiscal year;

AGE-Number of years coverage by Compustat prior to the late filing

BHAR12-12 months buy-and-hold abnormal return beginning 12 months before and ending at the filing deadline;

Stock PRICE-stock market price at the filing deadline;

Volume-volume of shares traded at deadline

Shares outstanding-\# of shares outstanding at deadline

Estimated default frequency-measure of bankruptcy risk in KMV-Merton model 
$\mathbf{N}=3,371$

\begin{tabular}{|c|c|c|c|c|}
\hline \multirow[b]{2}{*}{ Variable } & \multirow[b]{2}{*}{ Expected Sign } & \multicolumn{3}{|c|}{ Model 5B } \\
\hline & & Coefficient estimate & p-value & $\begin{array}{c}\text { Odds- } \\
\text { Ratio } \\
\text { (point } \\
\text { estimate) }\end{array}$ \\
\hline INTERCEPT & $?$ & -2.04 & $<0.001$ & \\
\hline$\underline{\text { Test variables }}$ & & & & \\
\hline NT & + & 0.56 & $<0.001$ & 2.45 \\
\hline Control variables & & & & \\
\hline MVE & - & -0.00 & 0.90 & 1 \\
\hline Age & $?$ & -0.01 & 0.07 & 1 \\
\hline BHAR12 & - & -0.50 & 0.01 & 0.86 \\
\hline Stock Price & - & -0.02 & 0.05 & 1 \\
\hline Volume & - & 0.00 & 0.56 & 1 \\
\hline Shares outstanding & - & -0.00 & 0.30 & 1 \\
\hline $\begin{array}{l}\text { Estimated default } \\
\text { frequency }\end{array}$ & + & 1.42 & $<0.001$ & 6.74 \\
\hline Pseudo-R2 $\quad 0.06$ & & & & \\
\hline
\end{tabular}

All explanatory variables have been truncated at $1 \%$ level.

Variables' Definitions:

NT-a dummy variable coded 1 for all late filing notifying firms and 0 otherwise;

MVE-market value of equity in the end of the fiscal year;

AGE-Number of years coverage by Compustat prior to the late filing

BHAR12-12 months buy-and-hold abnormal return beginning 12 months before and ending at the filing deadline; Stock

PRICE-stock market price at the filing deadline;

Volume-volume of shares traded at deadline

Shares outstanding-\# of shares outstanding at deadline

Estimated default frequency-measure of bankruptcy risk in KMV-Merton model 
Dependent Variable: FBHAR12

\section{Dependent Variable: FBHAR12}

\begin{tabular}{|c|c|c|c|c|}
\hline \multirow[b]{3}{*}{ Variable } & \multicolumn{2}{|l|}{$\mathbf{N}=24,559$} & \multicolumn{2}{|l|}{$\mathbf{N}=7,872$} \\
\hline & \multicolumn{2}{|c|}{ Model 6-A } & \multicolumn{2}{|c|}{ Model 6-B } \\
\hline & $\begin{array}{c}\text { Coefficient } \\
\text { estimate }\end{array}$ & p-value & $\begin{array}{c}\text { Coefficient } \\
\text { estimate }\end{array}$ & p-value \\
\hline INTERCEPT & 0.04 & $<0.0001$ & 0.03 & $<0.0001$ \\
\hline Test variables & & & & \\
\hline Late & -0.04 & 0.00 & -0.06 & 0.05 \\
\hline Control variables & & & & \\
\hline BHAR12 & -0.07 & $<0.0001$ & -0.06 & $<0.0001$ \\
\hline SURP1 & 0.04 & 0.35 & & \\
\hline SURP2 & 0.00 & 0.7 & & \\
\hline SURP3 & 0.02 & 0.64 & & \\
\hline SURP4 & 0.03 & 0.01 & & \\
\hline FERR1 & & & 0.04 & 0.95 \\
\hline FERR2 & & & -1.52 & 0.07 \\
\hline FERR3 & & & 0.19 & 0.75 \\
\hline FERR4 & & & -1.02 & 0.01 \\
\hline FUT_DELIST & -0.06 & 0.17 & -0.12 & 0.15 \\
\hline FUT_DELIST*LATE & -0.46 & $<0.0001$ & -0.13 & 0.66 \\
\hline RESTATE & -0.1 & 0.03 & 0.00 & 0.93 \\
\hline RESTATE*LATE & -0.11 & 0.34 & -0.35 & 0.08 \\
\hline
\end{tabular}

All explanatory variables have been truncated at $1 \%$ level.

Variables Definitions:

FBHAR12-12 month size-adjusted buy-and-hold abnormal return cumulated from the filing deadline LATE-a dummy variable coded 1 for all late filing firms and 0 otherwise;

FUT_DELIST-a dummy variable coded 1 for all firms that delist within 1 year of the filing deadline

RESTATE-a dummy variable coded 1 for all firms that restate within 1 year of the filing deadline

SURP1-SURP4-quarterly random walk forecast errors in the year of the late filing deflated by prior year stock priceFERR1-FERR4- quarterly forecast errors in the year of the late filing 


\section{MVE200 $=0$ NT $=0$ Delist $=1$}
fbhar12
12
$-0.4895091$
** $0.0161-0.8312373$

MVE200 $=0$ NT $=1$ Delist $=0$
fbhar12
1230
0.0048593
$0.9061 \quad-0.2672619$

\section{MVE200=0 NT=1 Delist=1}
fbhar12
51
$-0.652376$
$<.0001 \quad-0.9218547$

MVE200 $=1 \mathrm{NT}=0$ Delist $=0$

fbhar12

538

$-0.006253$

$0.7799 \quad-0.0503678$

\section{MVE200=1 NT=0 Delist=1}

fbhar12

9

$-0.1291535$

$0.542-0.1114572$

MVE200 $=1$ NT $=1$ Delist $=0$
fbhar12
201

$-0.0132708$

0.7734

$-0.1284261$

MVE200=1 NT=1 Delist=1

fbhar12 7

$-0.7910753$

$0.0019-0.9090296$

Variables Definitions:

MVE200 $=1$ if market value of equity $>=\$ 200 \mathrm{mln} ; 0$ otherwise

$\mathrm{NT}=1$ if the firm notifies of its intention to file late; 0 otherwise;

DELIST $=1$ if the firm delists in the 12 months following the deadline; 0 otherwise;

FBHAR12 is the 12 month buy-and-hold size-adjusted abnormal return cumulated from the filing deadline 
not survive 12 months after the deadline) :

\begin{tabular}{|llll}
\hline $\mathrm{N}$ & Mean & Std Dev & Median \\
\hline
\end{tabular}

\section{MVE200 $=0$ NT $=0$}

\section{fbhar12s \\ MVE200 $=0$ NT $=1$}

fbhar12s

MVE200 $=1$ NT $=0$

fbhar12s

MVE200 $=1$ NT=1

fbhar12s
708

$-0.09^{* * *}$

1652

$-0.24^{* * *}$

1.32

$-0.47^{* \star *}$

547

$-0.01$

221

$-0.09 * *$

0.68

$-0.18^{* * *}$

\section{Variables Definitions:}

MVE200 $=1$ if market value of equity $>=\$ 200 \mathrm{mln} ; 0$ otherwise

$\mathrm{NT}=1$ if the firm notifies of its intention to file late; 0 otherwise;

DELIST $=1$ if the firm delists in the 12 months following the deadline; 0 otherwise;

FBHAR12s is the 12 month buy-and-hold size-adjusted abnormal return cumulated from the filing deadline that includes simulated BHARs of -1 for any firm that delists prior to the end of 12 month period. 